
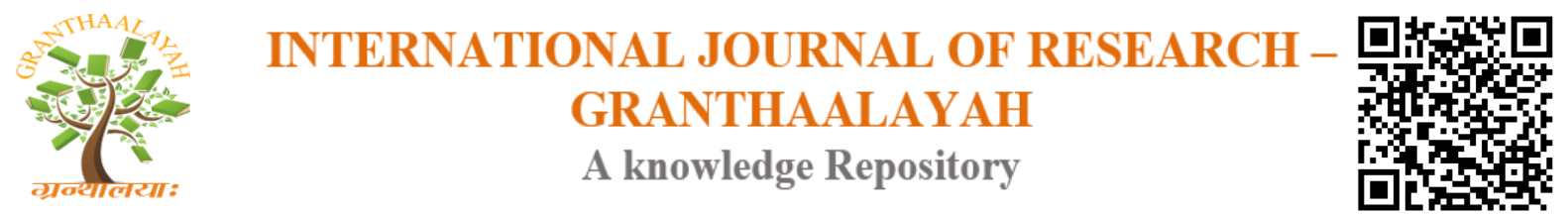

Management

\title{
AN ANALYTICAL STUDY OF FINANCIAL DISTRESS AND PROFITABILITY OF SBI AND ICICI BANK
}

\author{
Priyanka $^{* 1}$, Dr. Karamvir Sheokand ${ }^{2}$ \\ ${ }^{* 1}$ Assistant Professor, Govt. College, Meham Rohtak, Haryana, India \\ ${ }^{2}$ Assistant Professor, Imsar, Maharshi Dayanand University, Rohtak, Haryana, India
}

\begin{abstract}
Financial distress is a situation in which a firm or company is not in position to pay its monetary obligation and debts and financial crisis start in the unit. It depicts the short term solvency of the banks. Profitability is the ability of business to earn profit. Profitability is the indication of good health of any business and it increase the value of a business. The main aims of this research paper are to investigate the level of financial distress in the SBI and ICICI bank and difference in the profitability of both banks ranging from 2013 to 2017. For measurement of the level of financial distress and profitability Altman Z-Score model and Independent t-test are used respectively. Result revealed that profitability of both banks was identical. Further study also revealed that both these banks were financially distressed.
\end{abstract}

Keywords: Financial Distress; Profitability; Ratios.

Cite This Article: Priyanka, and Dr. Karamvir Sheokand. (2017). "AN ANALYTICAL STUDY OF FINANCIAL DISTRESS AND PROFITABILITY OF SBI AND ICICI BANK." International Journal of Research - Granthaalayah, 5(8), 79-84. https://doi.org/10.29121/granthaalayah.v5.i8.2017.2185.

\section{Introduction}

Banks are the backbone of any economy. SBI and ICICI banks are the largest bank in public and private sector respectively. Both are in leading position in their respective sector. SBI was nationalized in 1955 and become a largest bank in public sector in India. It has 5 associates' banks which were merged in SBI on $1^{\text {st }}$ April 2017.ICICI (Industrial Credit and Investment Corporation of India) bank was found on 1994. It is a multinational bank and deal in various financial services. ICICI is the $2^{\text {nd }}$ largest bank in terms of assets and $3^{\text {rd }}$ largest bank in terms of market capitalization. Financial distress is an emerging issue in today scenario and a hot topic of discussion. Bank crisis cause adverse effect on the economy and health of financial sector. Generally, Financial distress is a situation in which a firm or company is not in position to pay its monetary obligation and debts and financial crisis start in the unit. When a bank is facing financial distress, at that time its market value of share is reduced and customers avoid dealings with that bank. If a bank is facing crucial situation of distress, people loss their faith in entire 
banking system and avoid dealings. There are mainly two type of failure: 1) Economic failure is a situation, where revenues are less than the cost of its operations. 2) Financial failure is a situation, where firm has operating profit but unable to meet out its debt to its customers. Financial distress cost include the cost of the bankruptcy, distressed assets, sale of distressed assets, higher cost of capital and conflicts of interest. Calculating the financial distress of banks, bank has its own motive because it can point the financial position and profitability of banks. All the parties are interested in the financial position because it's an indication or signal to the stakeholders and investors for their investment decision. To check out the distress Altman ' $\mathrm{Z}$ score model is used. It is widely used model for distress and bankruptcy in banking sector as well as in corporate sector. Altman Z-Score model is published in 1968 by Edward I. Altman 'Zscore' model is a composition of different ratios into a single score. It uses the profitability, solvency, liquidity, leverage and activity ratios to measures the insolvency or bankruptcy of any company or any bank. This model can be break down into five major ratios. These are as follows:

$\mathrm{Z}=1.2 \mathrm{X} 1+1.4 \mathrm{X} 2+3.3 \mathrm{X} 3+0.6 \mathrm{X} 4+1.0 \mathrm{X} 5$

$\mathrm{X} 1$ = working capital / total assets

$\mathrm{X} 2=$ retained earnings / total assets

$\mathrm{X} 3=\mathrm{EBIT} /$ total assets

$\mathrm{X} 4=$ market value of equity / book value of total liabilities

$\mathrm{X} 5=$ sales $/$ total assets

To check out the profitability of banks 'independent t-test 'can be used. Independent t-test is also called the two sample t-test. It determines that there is any statistical difference between two means of unrelated groups or not. Profitability is the ability of business to earn profit. Profitability is the indication of good health of any business and it increase the value of a business. EBIT of the both banks taking into consideration in this study.

\section{Review of Literature}

Over the past decades various studies have been conducted to predicting the bankruptcy in banking sector and corporate sector in India as well as all over the world. Here are some literatures which are helped us for our study as follow:

Rajeskar, T.et. al. (2014) examined the level of distress with the help of Altman Z-Score model and CA-Score model. In this paper researcher analyze the bankruptcy of navratna enterprises in India. Out of the 14 navratna companies 8 companies were found financially weak for some years.

Lai, HuiYind et.al. (2014) conducted a study on the impact of 2008 global financial crises on public listed construction companies. A sample of 32 public listed companies is taken out of 60000 construction companies. Altman Z-Score was used in present study for analysis. The study elucidate that financial crises has direct impact on profitability. 
Kumar and Gulati (2008) evaluating the technical efficiency of 27 public sector banks operating in India. Data Envelopment Analysis Model and Anderson and Petersen's Super Efficiency Model are used to measure the technical efficiency. Results of the present study reveals that only 7 banks out of 27 were technical efficient.

Das and Ghosh (2007) used Keynesian macro model to analyze the impact of direct lending on the profitability and solvency of banks. The study found that under certain conditions a programme of direct credit helped to raise the banks' profitability but in some other instances it led to low level of bank profit and also threatened the solvency of banks in the long time period.

\section{Objective of the Study}

The main objective of this study is to examine the level of financial distress of SBI and ICICI banks. Further this study investigates that whether there is any difference in the profitability of SBI and ICICI banks.

\section{Hypothesis of the Study}

In this study we examine that whether there is any difference in the profitability of two banks or not. Here, profits of both these banks are our independent variables. To study the hypothesis, we apply independent T-test.

$\mathrm{H}_{0}=$ There is no significant difference between the profitability of two banks.

$\mathrm{H}_{1}=$ There is significant difference between the profitability of two banks.

\section{Scope of Study}

Under this study we assess the level of financial distress and profitability of SBI and ICICI banks. The time period of the present study would be ranging from 2013 to 2017. Under this study secondary data of both banks would be used to assess the level of distress and profitability. Various variables like solvency, liquidity, activity and leverage etc. are taking into consideration to measure the level of financial distress.

\section{Data Source}

Information for any research has been collected from primary and secondary source. 1) Primary data is first-hand information which is collected for the specific purpose by researcher. 2) Secondary data is collected by someone else for their purpose and used by invigilator for another purpose. In this research paper secondary data is used. Data were collected from various websites and annual financial statements of the respective banks. The study has used various financial ratios which are calculated on the basis of the secondary data.

\section{Results and Interpretation}

The study has used independent t-test to check whether there is any significant difference in the profitability of the SBI and ICICI banks and Altman Z-score model to measure the level of financial distress of banks. 


\section{Independent t-test}

The independent-samples t-test (or independent t-test, for short) compares the means between two unrelated groups on the same continuous, dependent variable. Independent t-test is also called the two sample t-test.

Table 1: Descriptive Statistics

\begin{tabular}{|l|l|l|l|l|l|}
\hline & BANK NAME & N & Mean & Std. Deviation & Std. Error Mean \\
\hline \multirow{2}{*}{ Profits } & SBI & 5 & 11706.60 & 1798.718 & 804.411 \\
\cline { 2 - 6 } & ICICI & 5 & 9767.40 & 1008.280 & 450.916 \\
\hline
\end{tabular}

The above table depicts the mean and standard deviation of SBI and ICICI bank of last five years ranging from 2013 to 2017. From the above table we found that there is a marginal difference between the mean of two banks although standard deviation of SBI bank is very higher compare to ICICI bank. So there is a huge fluctuation between the profits of these two banks. The mean profit of SBI and ICICI banks are 11706.60 and 9767.40 respectively. Standard deviation of these two banks are 1798.72 and 1008.28 respectively which shows that the range of SBI banks profits is 9907.28 to 13505.32 and ICICI bank is 8759.12 to 10775.68 . Here we conclude that from above table that there is high ups and downs in profits of SBI bank from last five years compare to ICICI bank. ICICI bank earns consistent profit with least fluctuation as compare to SBI.

Table 2: Independent Sample Test

\begin{tabular}{|c|l|l|l|l|l|l|}
\hline \multicolumn{2}{|c|}{} & \multicolumn{2}{|c|}{$\begin{array}{c}\text { Levene's Test for } \\
\text { Equality of Variances }\end{array}$} & \multicolumn{2}{c|}{ Test of Equality of Means } \\
\cline { 2 - 7 } \multicolumn{2}{|c|}{} & F & Sig. & t & df & Sig. (2-tailed) \\
\hline Profits & $\begin{array}{l}\text { Equal variances } \\
\text { assumed }\end{array}$ & 4.575 & .065 & 2.103 & 8 & .069 \\
\cline { 2 - 7 } & $\begin{array}{l}\text { Equal variances } \\
\text { not assumed }\end{array}$ & & & 2.103 & 6.288 & .078 \\
\hline
\end{tabular}

The above table is an independent sample test which is divided into two parts: The first part which is Levene's Test for Equality of Variance and the second one is the Test of Equality of Means. One of the assumption of T-test is there should be equality of variances between different samples. So Levene's Test is used to assess the equality of variance for variable calculated for two or more groups. In the above table the value of sig. is .065 which is greater than the significant level (.05) so null hypotheses is accepted and conclude that both samples have equal variance. Once the Levene's test hypothesis is accepted, we select the P-value from equal variance assumed row. The p-value is compare with the 0.05 at 95 per cent confidence level. In the above table, p-value is .069 which is greater than the .05 . So we accept the null hypothesis and conclude that there is no significant difference between the means of two banks.

\section{Altman Z-Score Model}

Altman Z-Score Model is used to measure the level of financial distress and bankruptcy of organizations. Higher value in Altman Z-Score Model implies that bank is far from insolvency or 
distress. Altman Z-Score Model has mainly three zones which show the level of distress. These are follows:

$Z>2.99$ (Safe zone)

$1.81<Z>2.99$ (Gray zone)

$\mathrm{Z}<1.81$ (Distress zone)

Table 3: Financial Distress

\begin{tabular}{|l|l|l|}
\hline Year & SBI & ICICI \\
\hline 2013 & .2986 & 1.023 \\
\hline 2014 & .3207 & .2575 \\
\hline 2015 & .191 & .2534 \\
\hline 2016 & .270 & .2978 \\
\hline 2017 & .186 & .3168 \\
\hline
\end{tabular}

The above table depicts the year wise level of financial distress of SBI and ICICI bank for the period ranging from 2013- 2017 which is calculated with the help of Altman Z-Score model. Throughout Z-Score value of ICICI bank is higher than the SBI bank except in 2014 where SBI is in better condition. Both these banks were suffering from financial distress although ICICI is in better condition than SBI because there is less fluctuation in the profits of ICICI banks as compare to SBI.

\section{Findings of the Study}

The main objectives of the study were to examine the level of financial distress of ICICI and SBI banks and to investigate the difference in the profitability of the both banks. Profits of the last five years were taken as sample of the study of both banks. It is observed from the above study that p-value for equal variance is .069 which is greater than the .05 and null hypothesis is accepted. There is no significant difference in the profitability of the both the banks because of the well capital structure, good financial position of the banks and large market capitalization. One of the reasons that both banks were suffering from the financial distress is due to excess burden of current liabilities.

\section{Conclusion}

The study concludes that there is no significant difference in the profitability of the both banks and both banks suffering from the financial distress. There may be many reason for financial distress. It is very important for both banks to come out from the situation of distress. Associates of SBI bank and Bhartiya Mahila Bank are going to merge with the SBI bank to enhance the level of SBI globally and increase their capital structure and competency. Recently SBI has reduced their interest rate on saving account having balance of up to one cr. from 4 to 3.5 per cent. ICICI bank invested most of their savings in different securities to keep their financial position strong. In the end we conclude that both banks short term solvency is vulnerable although in long run both these banks are excellent. 


\section{References}

[1] Das, A., \& Ghosh, S. (2007). Determinants of credit risk in Indian state owned banks: An emperical investigation. Economic Issue 12, no. 2, 27-46.

[2] Fulmer, J. G., Moon, J. E., Gavin, T. A., \& Ervin, M. J. (1984). A bankruptcy classification model for small firms. Journal Of Commercial Bank Lending, 25-37.

[3] Kumar, S., \& Gulati, R. (2008). Evaluation of technical efficiency and ranking of public sector banks in India: An analysis of cross sectional perspective. International Journal Of Productivity And Performance Management, 51 no. 7, 540-548.

[4] Lai, H. Y., Aziz, A. R., \& Chan, T. K. (2014). Effect of global financial crisis on the financial performance of public listed construction companies in Malaysia. Journal of Financial Management of Property and Construction, 19 (3), 246-263.

[5] Malcom, S., \& Liou, D. K. (2007). Industrial sector and financial distress. Managerial Auditing Journal, 22 (4), 376- 391.

[6] Rajeskar, t., Ashraf, S., \& Deo, M. (2014). An empirical enquiry on financial distress of navratna companies in India. Journal of Accounting And Finance, 100-106.

[7] www.moneycontrol.com

[8] www.sbi.com

[9] www.icici.com

[10] www.rbi.org.in

*Corresponding author.

E-mail address: 05priyankasoni@ gmail.com 